\title{
13. MANGANESE MICRONODULES IN SEDIMENTS: A SUBSURFACE IN-SITU ORIGIN, LEG 51, DEEP SEA DRILLING PROJECT
}

\author{
P.E. Borella, Riverside City College, Riverside, California \\ and \\ C. Adelseck, Deep Sea Drilling Project, Scripps Institution of Oceanography, La Jolla, California
}

\begin{abstract}
Rhodochrosite crystals and manganese oxide micronodules which have formed in situ are found in abundance at depth $(76.5$ to $106.5 \mathrm{~m})$ in Hole 417A. A gradual transformation of the rhodochrosite to manganese oxide micronodules is observed in many grains throughout the interval. The transformation process initially attacks the edge of the rhodochrosite crystal and proceeds inward, first forming a pseudomorph of the crystal. Some grains exhibit varying degrees of departure from the crystal shape of a true pseudomorph, suggesting either an overgrowth of manganese oxide or late-stage destruction of the pseudomorph.

No significant differences were observed in the relative per cent of minor and trace metals when comparing the pure rhodochrosite with the manganese oxide pseudomorphs. This suggests that the manganese and other trace elements were not transported into the system but were incorporated directly from the rhodochrosite as the manganese oxide formed. Grains which did not exhibit pseudomorphic form showed enrichment in some trace elements.

We postulate that the diagenetic environment changed from reducing to oxidizing. How and when this change occurred in the sedimentary column remains an enigma.
\end{abstract}

\section{INTRODUCTION}

This study deals with in-situ formation of hydrated manganese oxide grains (micronodules?) and rhodochrosite crystals which were observed in samples from DSDP Sections 417 A-9-2 to 417 A-12-2 (76.5 to $106.5 \mathrm{~m}$ subbottom). The sediment in which these minerals are found is a pelagic clay ranging in color from yellowish brown and pale brown to dark brown. It is highly disturbed by drilling, and no definite bedding or sedimentary structures were preserved. Scattered throughout this interval are zones of volcanic ash which are mostly light blue-gray to greenish gray and generally appear as small lenses or blebs surrounded by the pelagic clay. Clay minerals comprise approximately 80 per cent of the unit by volume. Smectite, illite, and kaolinite are the major clay minerals (see X-ray Mineralogy, Site 417 Report). Associated with the rhodochrosite in the coarse fractions (silt and sand) are fish debris, Fe-Mn nodules, and altered volcanic rock fragments. No foraminifers or radiolarians were recovered.

The occurrence of rhodochrosite and manganese micronodules has been reported in other DSDP cores. Beall and Fischer (1968) reported manganese oxide present in small nodules in the red clays of DSDP Site 7, with rhodochrosite in the same cores. Rex (1970) and Peterson et al. (1970) mention the presence of siderite, rhodochrosite, and iron-manganese nodular material at the base of the sediment section in Hole 9A of DSDP Leg 2. They attributed the coexistence of these mineral species to hydrothermal mineralization. Berger and von Rad (1972) report rhodochrosite in two crystal forms, blocky and elongate, in the proximity of manganese concretions at DSDP Site 137. They postulated that oxygenated bottom waters would allow the formation of manganese oxides and prevent manganese from escaping the sediment. Introduction of reduced carbon-rich sediments (displaced from shallower areas in the oxygen minimum zone) would allow manganese carbonate to form. However, evidence in support of these hypotheses is lacking.

The literature on manganese micronodules and grains of hydrated manganese oxides in deep-sea sediments is sparse; however, the literature on manganese macronodules is extensive. Excellent summaries of their mineral and trace element composition, modes of formations, accretion rates, and geographic distribution are discussed by Mero (1962, 1965), Arrhenius (1963), Horne (1969), Riley and Chester (1971), and Cronan (1973). The distribution and composition of manganese nodules with depth in deep-sea cores is discussed by Cronan and Tooms (1967), Chester and Hughes (1966), Cronan (1973), and Menard (1976). Most of these workers agree that the formation of nodules takes place at the sediment surface as a precipitate from sea water or due to upward diffusion of reduced manganese from deep in the sediment (Bonatti and Nayuda, 1965). As yet, no conclusive evidence has been presented for the subsurface formation of manganese nodules, micronodules, or other hydrated manganese oxides. 


\section{PROCEDURES}

Rhodochrosite crystals and manganese oxide micronodules were found in association in (probably) Oligocene to upper Eocene Cores 417A-9 to 417A-12. Examination of the rhodochrosite crystals revealed a gradation from entirely pink grains to entirely black opaque grains, considered to be manganese micronodules by the sedimentologists onboard. Additional samples in the interval were taken and separated into clay, silt, and sand-size fractions, using a vibrating wet-sieving apparatus attached to a vacuum pump. The rhodochrosite and manganese oxide grains were removed. Splits from the samples were mounted on slides with Caedex $(n=1.535)$ for petrographic study and microphotography. Approximately 100 grains of rhodochrosite (pink with no visible black stains on crystals) were picked, powdered, and mounted onto a silver filter for X-ray diffraction analysis. A similar procedure was done for 100 grains of "completely transformed rhodochrosite" distinguished by being completely black and opaque in transmitted and polarized light, but having the same crystal form as the rhodochrosite (i.e., pseudomorphs).

$\mathrm{X}$-ray diffraction analysis was performed using $\mathrm{CuK} \alpha$ radiation with an attached monochronometer which enables manganese oxide to be identified. Identification of minerals was made using the Joint Committee on Powder Diffracting Standards (JCPDS).

Lastly, selected samples were mounted on stubs for analysis using a scanning electron microscope with an attached ORTEC energy-dispersive X-ray elemental analyzer. All measurements of major, minor, and trace element abundances are expressed as intensity ratios in counts of that element per total counts for all elements analyzed. Although the data are only semiquantitative, trends in elemental abundances are evident.

\section{RESULTS}

We want to establish whether or not rhodochrosite and manganese oxides were the end members in a continuous transformation series. Comparison of the X-ray diffraction patterns (Figure 1) of the end members supports this interpretation. The rhodochrosite is being transformed into hydrated manganese oxides with the major peaks occurring at d-spacings of $2.84\left(31.45^{\circ} 2 \theta\right)$ for rhodochrosite and 3.40 $\left(26.0^{\circ} 2 \theta\right)$ for hydrated manganese oxide.

The transformation process of rhodochrosite being replaced by manganese oxide is pictorially seen in Plate 1 . The rhodochrosite appears as hexagonal elongate crystals with most exhibiting well-formed faces, many of which were also twinned. A second blocky form was observed (Plate 1) that was mostly hexagonal in shape, although some crystals appeared rhombohedral. The presence of these well-formed crystals, many of which are unabraded and show no signs of mechanical transport, is a clear indication that the crystals were formed in situ. The transformation series was observed in both crystal forms and was not restricted to any core. This gradual "creeping" transformation appears to attack the edges of the rhodochrosite making its way inward and eventually converting the manganese carbonate crystal to manganese oxide (Plate 1). The manganese oxide pseudomorphs in some grains are poorly defined (Plate 1, Figure 7), suggesting a process of either continued growth of manganese oxide on the pseudomorph or late-stage destruction of the pseudomorph.

Micronodules exist in all sand and silt-size fractions within the sediments and tend to be aggregated into clusters in the finer fractions (Plate 2). Because of the highly disturbed and mixed nature of the sediments recovered at Hole $417 \mathrm{~A}$, it is not possible to state whether they are genetically related to the rhodochrosite manganese oxide transformation. They may or may not represent an entirely separate process and period of formation of manganese oxide.

Elemental analysis of the rhodochrosite, manganese oxide pseudomorphs, and micronodules (Table 1) showed that relative to manganese, the elements silicon, calcium, aluminum, and potassium were most abundant. These elements show a variability in relative abundance for the different analyses. We interpret this as being the result of absorption and incorporation of sediment (dominantly clay) during formation of either the rhodochrosite or the pseudomorph. The elements found in minor or trace amounts $(\mathrm{Cu}, \mathrm{Ni}, \mathrm{Ti}, \mathrm{Fe}, \mathrm{Co}, \mathrm{Mg})$ showed no significant differences when comparing the pure rhodochrosite crystals (Plate 3) to the manganese oxide pseudomorphs (Plate 4). We suggest this indicates that the trace elements incorporated into the manganese oxide were present in the rhodochrosite. It further suggests that the transformation was an ion-by-ion exchange of oxygen and water for carbonate; thus, neither manganese nor the associated trace elements have apparently migrated into the system during the transformation.

Elemental analysis of a manganese oxide cluster (Plate 5 ), which has a nodular shape, showed significant minor or trace element enrichment as compared to the rhodochrosite and manganese oxide pseudomorphs (Table 1). Such clusters may represent a final stage of overgrowth of the pseudomorph, as mentioned earlier, or may be totally unrelated to the rhodochrosite-manganese oxide transformation series. In addition, a concretionary growth attached to a rhodochrosite crystal was observed (Plate 5). Elemental analysis of the concretion also showed relative enrichment in trace elements by comparison to the crystal on which it lies. We cannot be sure that the growth is manganese oxide since no X-ray diffraction pattern of it was obtained; however, its general appearance (no cleavage or hexagonal shape) and comparison to other grains of similar elemental composition (Plate 5) suggest that it is manganese oxide.

\section{DISCUSSION}

The question arises as to whether this transformation could be proceeding in the opposite direction, i.e., manganese oxide transforming into rhodochrosite. Examination of the data shows that this could not be the case. Primarily, it is not possible that the initial phase would exhibit the "pseudomorphic" form of the secondary one. Moreover, the transformation series shows that the manganese oxides occupy the surface of the grains while the rhodochrosite is found at the center. Thus, a manganese oxide to rhodochrosite transformation would require the improbable case of the transformation starting at the grains' interior and moving outward. All evidence thus supports a rhodochrosite to manganese oxide transformation. 


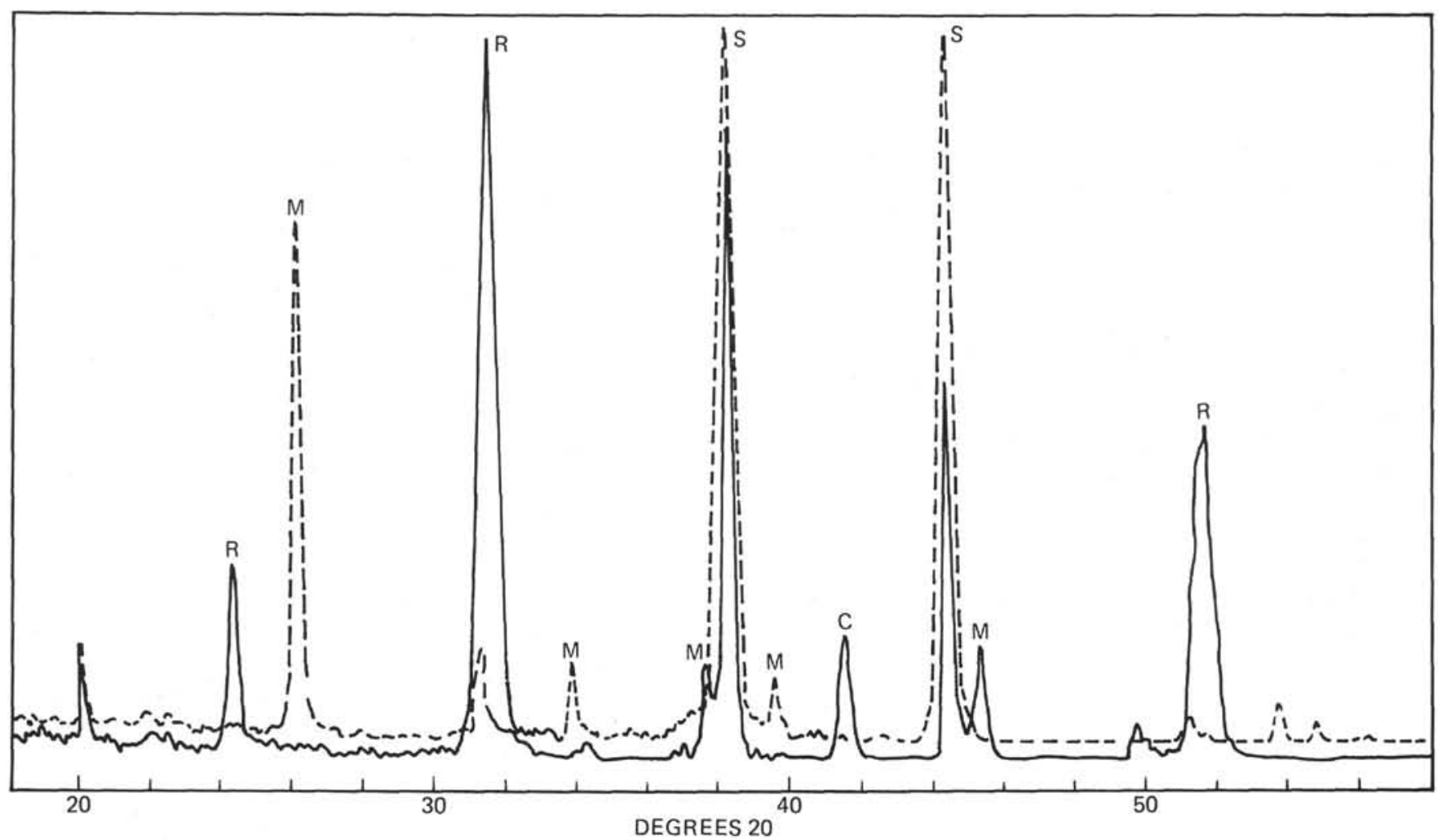

Figure 1. X-ray diffractogram of end members in transformation process. The solid line is the X-ray diffractogram for pure rhodochrosite crystals; the broken line is the X-ray diffractogram for the completely transformed (black) grains. $R=$ rhodochrosite $\left(\mathrm{MnCO}_{3}\right) ; \mathrm{M}=$ manganese oxide (hydrated) $\mathrm{Mn}_{2} \mathrm{O}_{3} \cdot \mathrm{H}_{2} \mathrm{O}, \mathrm{Mn}_{x} \mathrm{O}_{4} \cdot \mathrm{H}_{2} \mathrm{O} ; \mathrm{C}=$ calcium carbonate (hydrated) $\mathrm{CaCO}_{3} \cdot \mathrm{H}_{2} \mathrm{O}$ or a minor rhodochrosite $\left(\mathrm{MnCO}_{3}\right)$ peak; $\mathrm{S}=$ silver filter.

TABLE 1

Results of SEM Energy-Dispersive X-Ray Elemental Analysis

\begin{tabular}{|c|c|c|c|c|c|c|c|c|c|c|}
\hline \multirow{2}{*}{$\begin{array}{c}\text { Sample No. } \\
\text { (Interval in } \mathrm{cm} \text { ) }\end{array}$} & \multicolumn{10}{|c|}{ Elements (relative per cent of total counts ${ }^{\mathrm{a}}$ ) } \\
\hline & $\mathrm{Mg}$ & $\mathrm{Al}$ & $\mathrm{Si}$ & K & $\mathrm{Ca}$ & $\mathrm{Ti}$ & $\mathrm{Mn}$ & $\mathrm{FC}^{\mathrm{b}}$ & $\mathrm{Ni}$ & $\mathrm{Cu}$ \\
\hline $\begin{array}{l}10-3,101-103 \mathrm{~cm} \\
\text { pure rhodochrosite } \\
\text { (elongate) crystal }\end{array}$ & 0.2883 & 1.6284 & 3.2134 & 0.6312 & 4.6220 & 0.0304 & 89.3212 & 0.0104 & 0.0435 & 0.2321 \\
\hline $\begin{array}{l}11-3,54-56 \mathrm{~cm} \\
\text { pure rhodochrosite } \\
\text { (blocky) crystal }\end{array}$ & 0.1078 & 2.0461 & 0.4766 & - & 12.7401 & 0.2250 & 84.0300 & 0.0895 & - & 0.2850 \\
\hline $\begin{array}{l}9-3,130-132 \mathrm{~cm} \\
\text { completely transformed } \\
\text { (blocky) crystal }\end{array}$ & - & 3.0493 & 2.3932 & 0.3980 & 0.8019 & - & 92.9904 & 0.0530 & 0.0825 & 0.2316 \\
\hline $\begin{array}{l}10-3,101-103 \mathrm{~cm} \\
\text { completely transformed } \\
\text { (elongate-twinned } \\
\text { crystal) }\end{array}$ & 0.0922 & 0.8718 & 4.5245 & 0.9297 & 3.1018 & 0.0904 & 90.4416 & 0.1498 & 0.1310 & 0.1102 \\
\hline $\begin{array}{l}12-2,43-45 \mathrm{~cm} \\
\text { Mn nodular cluster }\end{array}$ & 0.5462 & 9.3588 & 17.0071 & 3.5989 & 2.1655 & 0.6162 & 64.4896 & 0.2457 & 1.3750 & 0.5970 \\
\hline $\begin{array}{l}9-3,130-132 \mathrm{~cm} \\
\text { growth on grain }\end{array}$ & 0.4499 & 1.6500 & 4.0242 & 2.7913 & 1.7871 & 0.9579 & 86.6257 & 0.5170 & 0.6775 & 0.5213 \\
\hline $\begin{array}{l}9-3,130-132 \mathrm{~cm} \\
\text { pure rhodochrosite } \\
\text { (crystal that growth } \\
\text { is on) }\end{array}$ & 0.0629 & 2.2592 & 0.0694 & 0.1843 & 1.9114 & 0.1386 & 94.8813 & 0.0331 & 0.0184 & 0.7060 \\
\hline
\end{tabular}

\footnotetext{
${ }_{\mathrm{b}}^{\mathrm{a}} \mathrm{Per}$ cents show the counts of any given element compared to the total counts for all 11 elements.

${ }^{\mathrm{b}} \mathrm{FC}=$ Iron and cobalt.
} 
When discussing the association of the different minerals and grains in these cores, it must be emphasized that the recovered intervals were totally mixed by drilling disturbance. Consequently, we probably have mineral associations within samples which do not naturally occur in the sediment. For example, we find all phases of the rhodochrosite to manganese oxide transformation within individual $10-\mathrm{cm}^{3}$ samples. It is difficult to explain such apparent differences in geochemical microenvironments within a length of a few millimeters. It is more likely that the transformation sequence is stratigraphically controlled with distinct zones of rhodochrosite, transitional grains, and manganese oxide pseudomorphs, but that these were mixed during drilling.

The geochemical problem with which we are faced is that of how the sedimentary environment sufficiently changed to promote the transformation of the rhodochrosite to hydrated manganese oxide. The theoretical stability fields of several common manganese oxide minerals are shown in Figure 2 as a function of $\mathrm{Eh}$ and $\mathrm{pH}$, at standard temperature and pressure. Rhodochrosite is stable over a wide range of Eh

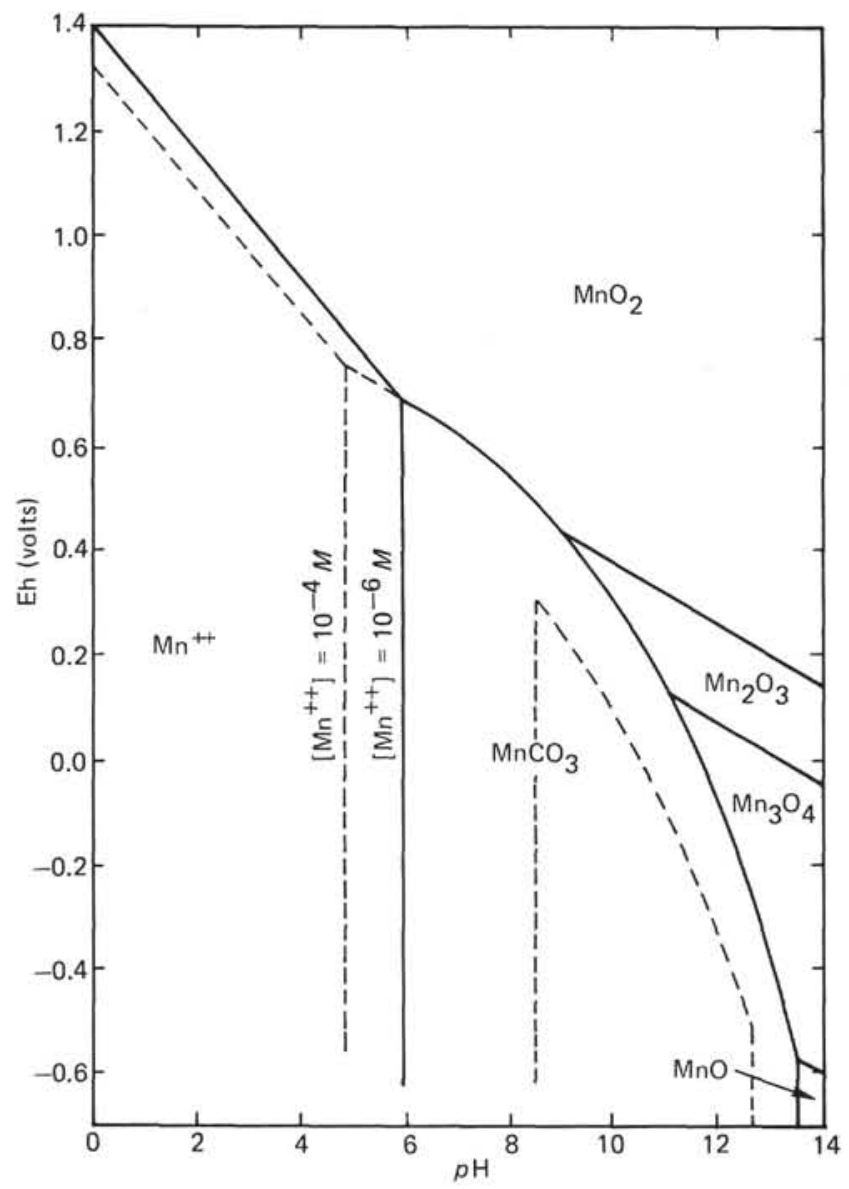

Figure 2. Eh- $\mathrm{pH}$ diagram showing stability fields of common manganese minerals. Assumed concentrations are: total carbonate, $1 \mathrm{M}$; total sulfur $10^{-6} \mathrm{M}$; manganese, as shown. The light dashed line shows rhodochrosite field if total carbonate concentration is $10^{-3} \mathrm{M}$. Diagram after Krauskopf, 1967. for the normal range of oceanic $p \mathrm{H}, 7.8$ to 8.3. We assume that $p \mathrm{H}$ has not fluctuated out of this normal range for the sediment from Hole 417A. No evidence for abnormal $p \mathrm{H}$ conditions is apparent in the interstitial water samples from these sediments (Gieskes, personal communication). Thus, the rhodochrosite transformation to manganese oxide, in the restricted range of oceanic $p \mathrm{H}$, requires an increase in the oxidation-reduction potential and a substantial amount of oxygen. Bricker (1965) determined oxygen requirements for some selected manganese carbonate reactions at $25^{\circ} \mathrm{C}$ at 1 atmospheric pressure. He concludes that approximately $1 / 2$ mole of oxygen is required to oxidize 1 mole of manganese carbonate. Under conditions of air-saturated water, Bricker estimates that it would take 1000 years to oxidize 0.3 meter of manganese carbonate ( $18 \%$ porosity). The rate of oxidation of this reaction in deep-sea sediments, where oxygen concentrations are much lower, would be considerably less. This suggests that too much time is required for the necessary reactions (both formation of rhodochrosite and transformation to manganese oxide) to have occurred at the sediment-sea water interface. The transformation must have occurred after burial.

Comparison of the theoretical stability fields (Figure 2) of manganese minerals with their distribution in natural environments (Figure 3) shows significant differences between the two. However, the general relationship be-

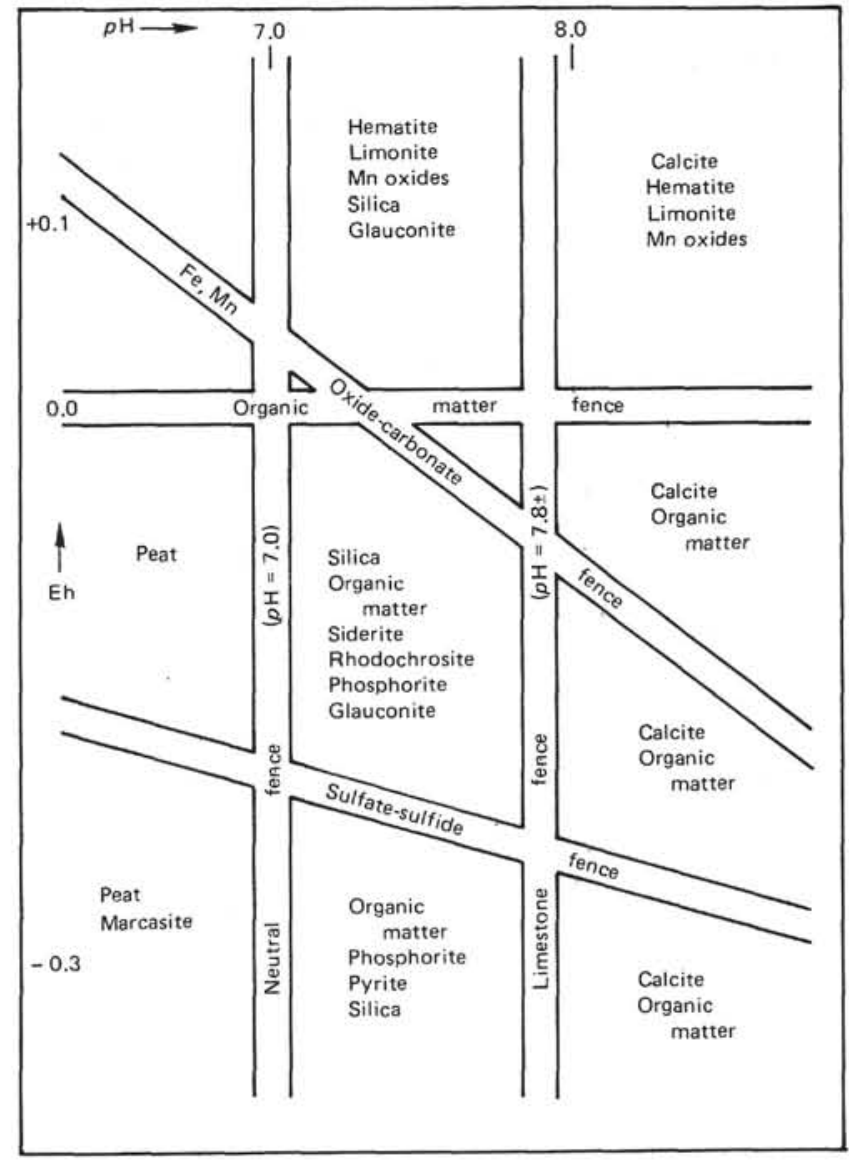

Figure 3. Sedimentary associations in relation to environmental limitations imposed by oxidation potential and $\mathrm{pH}$ (after Krumbein and Garrels, 1952). 
tween the rhodochrosite and manganese oxide fields remains similar. The association of rhodochrosite, manganese oxide, and transitional forms in the sediments at Hole 417A suggests that the Eh of the sediments may have been close to the value which separates the stability fields of the two minerals. The actual Eh value of this transition is dependent on in-situ temperatures and pressures. Gieskes (personal communication) has indicated that the sediments are now reducing, yet the color of the sediments (see Introduction) shows that the iron minerals exist in an oxidized state. The ammonia concentration in the interstitial water (Gieskes, this volume) shows a minimum inflection point at a depth of 54 meters. This would indicate higher Eh conditions just below the zone of the rhodochrosite to manganese oxide transformation. However, Gieskes considers this data point to be in error as a result of pore water reactions after the sediment core was retrieved.

It is important to note that the size of the $\mathrm{MnCO}_{3}$ field (Figure 2) is also a function of the total carbonate concentration in the system. An indication of how the field would shrink at a lower concentration is shown by the light dashed line (total carbonate equals $0.001 \mathrm{~m}$ ). At low concentrations of total carbonate, the manganese oxides would have larger stability fields; over much of the normal Eh- $p \mathrm{H}$ range, no manganese precipitate could form at all unless the $\left[\mathrm{Mn}^{++}\right]$is extremely high. It is theoretically possible to cause the transformation we observe by reducing the total carbonate concentration in the system.

In summary we can state that:

1) At present, the general state of the iron minerals in the sediment is oxidized.

2) The pore waters are presently reducing.

3) The sedimentary environment has changed from reducing to oxidizing and back again, or the concentration of total carbonate and/or manganese ion in the pore waters has significantly fluctuated.

4) Formation of the manganese oxide could only occur in the presence of free oxygen.

Thus, the exact mechanism causing the transformation cannot be specified, but since changes in Eh are evident, we suspect that fluctuations in the oxidation-reduction potential is the probable cause. The conditions which would produce these changes are presently unknown to us.

Lastly, we do not know when the transformation occurred. Because of the time necessary to initially form the rhodochrosite and then oxidize it to manganese oxide, we feel that the transformation could not have occurred at the sediment-sea water interface under normal sedimentation rates. However, we have no idea whether the transformation represents early or late stage diagenesis.

\section{CONCLUDING REMARKS}

We feel that there can be little doubt that the rhodochrosite crystals are diagenetic and have formed in situ at Hole 417A. A transformation from rhodochrosite $\left(\mathrm{MnCO}_{3}\right)$ to manganese oxide grains or nodules is clear. The transformation initially occurs at the edges of the rhodochrosite crystals and creeps inward, forming a manganese oxide pseudomorph. Some grains depart from true pseudomorphic form suggesting either continued growth of manganese oxide or else destruction of the pseudomorph. The change in chemical environment is probably one of increasing redox potential (Eh) for the transformation reaction.

This research has raised several questions which are important to our understanding and interpretation of manganese oxides grains in marine sediments. (1) Are the grains which we have observed in Hole 417A manganese micronodules? We feel that they are, but if not, other investigators may have also misidentified these manganese oxide grains. In either event, a clear definition of micronodules would be welcome. (2) Are the coexisting rhodochrosite and manganese micronodules reported from other DSDP sites linked as they are at Site 417? (3) How widespread is this type of transformation? (4) Could such a transformation process account for a significant portion of the micronodules found in sediments of any particular age?

\section{ACKNOWLEDGMENTS}

This manuscript was reviewed by J. Gieskes and J. Greenslate. The assistance of E. Flentye in the operation of the SEM and elemental analyzer is greatly appreciated. Many thanks are also extended to Dr. Gil Lang, M.D., who helped with the sampling while onboard the Glomar Challenger.

\section{REFERENCES}

Arrhenius, G., 1963. Pelagic sediments. In Hill, M. N. (Ed.), The Sea: New York (Interscience Publishers), v. 3, p. 655-727.

Beall, A. P., Jr. and Fischer, A. G., 1968. Sedimentology. In Ewing, M., Worsel, J. L., et al., Initial Reports of the Deep Sea Drilling Project, v. 1: Washington (U.S. Government Printing Office), p. 521-593.

Berger, W. H. and von Rad, V., 1972. Cretaceous and Cenozoic sediments from the Atlantic Ocean. In Hayes, D. E., Pimm, A. C., et al., Initial Reports of the Deep Sea Drilling Project, v. 14: Washington (U.S. Government Printing Office), p. 787-954.

Bonatti, E. and Nayuda, Y., 1965. The origin of manganese nodules on the ocean floor, Am. J. Sci., v. 263, p. 17-39.

Bricker, O., 1965. Some stability relations in the system $\mathrm{Mn}-\mathrm{O}_{2}-\mathrm{H}_{2} \mathrm{O}$ at $25^{\circ}$ and one atmosphere total pressure, $\mathrm{Am}$. Mineralogist, v. 50, p. 1296-1354.

Chester, R. and Hughes, M. J., 1966. Distribution of manganese, iron and nickel in a north Pacific deep sea day core, Deep-Sea Res., v. 18, p. 627-634.

Cronan, D. S., 1973. Manganese nodules and other ferromanganese oxide deposits. In Riley, J. P. and Chester, R. (Eds.), Introduction to marine chemistry: New York (Academic Press), Chap. 28, p. 217-263.

Cronan, D. S. and Tooms, J. S., 1967. Sub-surface concentrations of manganese nodules in Pacific sediments, Deep-Sea Res., v. 14 , p. $117-119$.

Horne, R. A., 1969. Marine chemistry, deposition of nodules and other accretions: New York (Wiley-Interscience), p. 400-420.

Krauskopf, K. B., 1967. Introduction to geochemistry: New York (McGraw-Hill), p. 262-268.

Krumbein, W. C. and Garrels, R. M., 1952. Origin and classification of chemical sediments in terms of $p \mathrm{H}$ and oxidation-reduction potentials, J. Geol., v. 60, p. 1-33.

Menard, H. W., 1976. Time, chance, and the origin of manganese nodules, $\mathrm{Am}$. Sci., v. 64 , p. $519-529$.

Mero, J. L., 1962. Ocean-floor manganese nodules, Econ. Geol., v. 51 , p. $747-767$. 
(Elsevier).

1965. The mineral resources of the sea: New York

Peterson, M. N. A., Edgar, N. T., von der Borch, C. C., Rex, R. W., 1970. Cruise summary and discussion. In Peterson, M. N. A., et al., Initial Reports of the Deep Sea Drilling Project, v. 2: Washington (U.S. Government Printing Office), p. $413-450$.
Rex, R. W., 1970. X-ray mineralogy studies, Leg 2. In Peterson, M. N. A. et al., Initial Reports of the Deep Sea Drilling Project, v. 2: Washington (U.S. Government Printing Office), p. $329-346$.

Riley, J. P. and Chester, R., 1971. Introduction to marine chemistry: New York (Academic Press), p. 359-369. 



\section{PLATE 1}

The transformation of rhodochrosite to manganese micronodules (Sample 417A-11-4, 130-132 cm.). Magnification $=7.8 \times$ plane light per cents of transformation are approximate.

Figure 1 Twinned rhodochrosite crystal; 0 to 5 per cent transformed.

Figure 2 A 20 per cent transformed rhodochrosite crystal. Note: dark areas in the left grain are manganese oxide.

Figure 3 A 40 per cent transformed rhodochrosite crystal. The manganese oxide is moving inward.

Figure 4 A 60 per cent transformed rhodochrosite crystal.

Figure 5 An 80 per cent transformed rhodochrosite crystal.

Figure 6 A 90 per cent transformed rhodochrosite crystal. Note: The crystalline form of the rhodochrosite grain is still preserved.

Figure 7 A 95 to 100 per cent transformed rhodochrosite grain (a manganese micronodule). Note: The crystalline form of the rhodochrosite is being destroyed.

Figure 8 Blocky hexagonal crystals of rhodochrosite. No manganese oxide is present on the grains. Sample $417 \mathrm{~A}-11-6,8-10 \mathrm{~cm}$.

Figure 9 Blocky rhodochrosite: upper grain is hexagonal, lower grain appears to be rhombohedral. Sample $417 \mathrm{~A}-9-4,38-70 \mathrm{~cm}$. (0 to $10 \%$ transformed).

Figure 10 Hexagonal (blocky) rhodochrosite crystals. Upper left grain is almost completely transformed to manganese oxide grain. Lower right rhodochrosite crystal is 0 per cent transformed. Sample 417A-10-3, 140-143 cm. 
PLATE 1

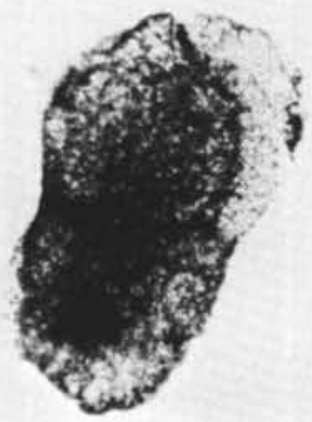

1

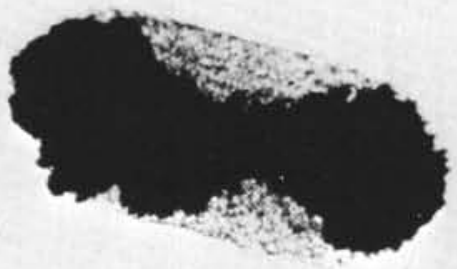

4
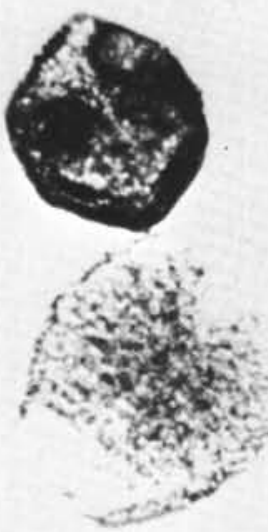

8

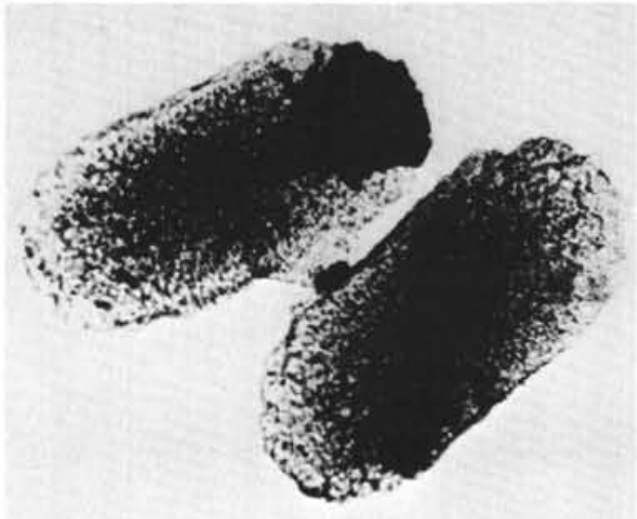

2

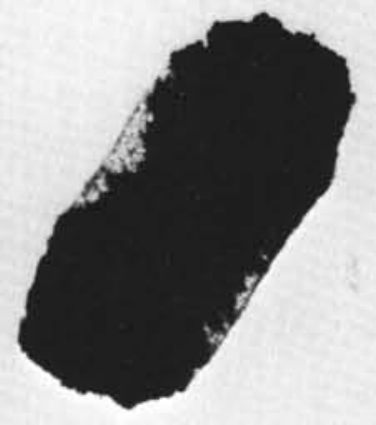

5

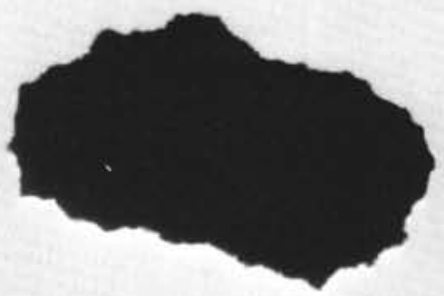

7

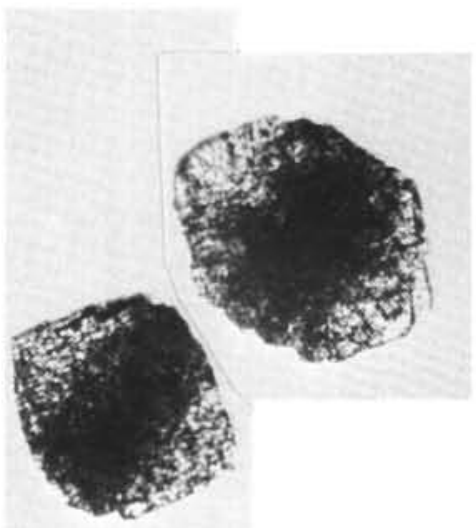

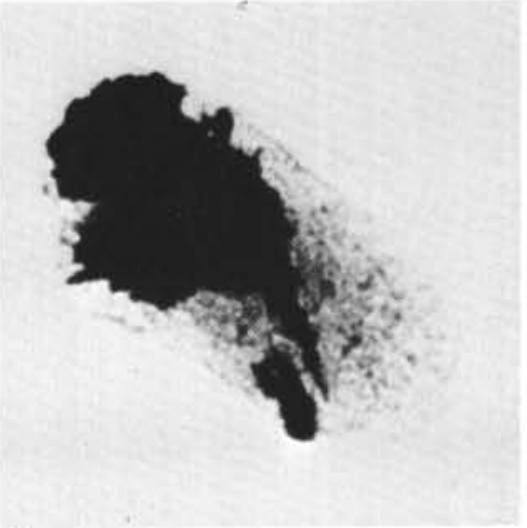

3

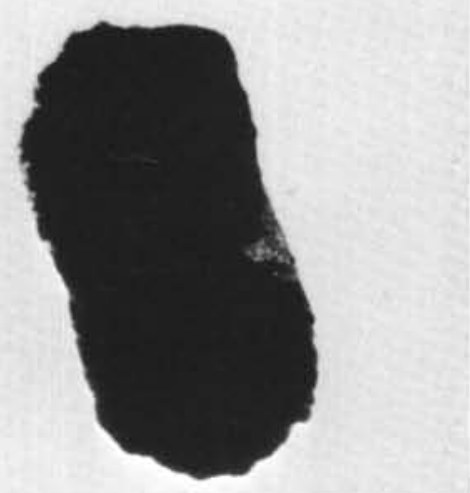

6

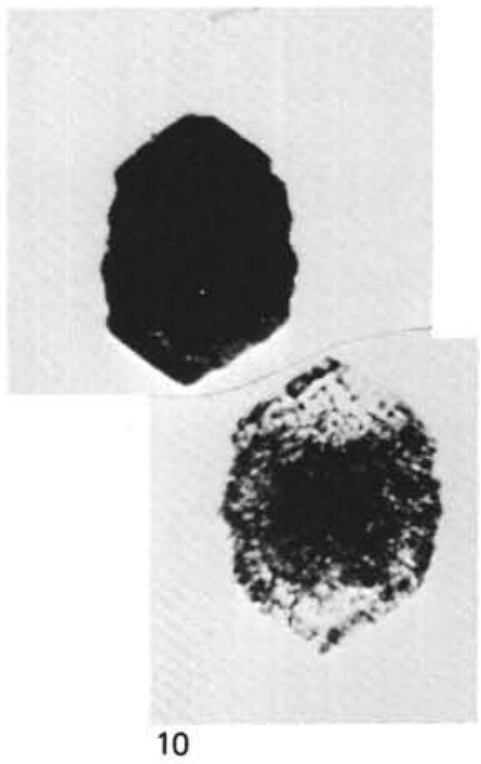




\section{PLATE 2}

Manganese micronodules (grains) and rhodochrosite in sand and silt size fractions in Sample 417A-9-3, 130-132 cm. Magnification 7.8×, plane light. (See text for explanation.)

Figure 1 Rhodochrosite and manganese oxide grains greater than 61 microns.

Figure 2 Manganese oxide grains in 45 to 61 micron size fraction.

Figure 3 Manganese oxide grains in 30 to 45 micron size fraction.

Figure 4 Manganese oxide grains in 16 to 30 micron size fraction. 


\section{PLATE 2}

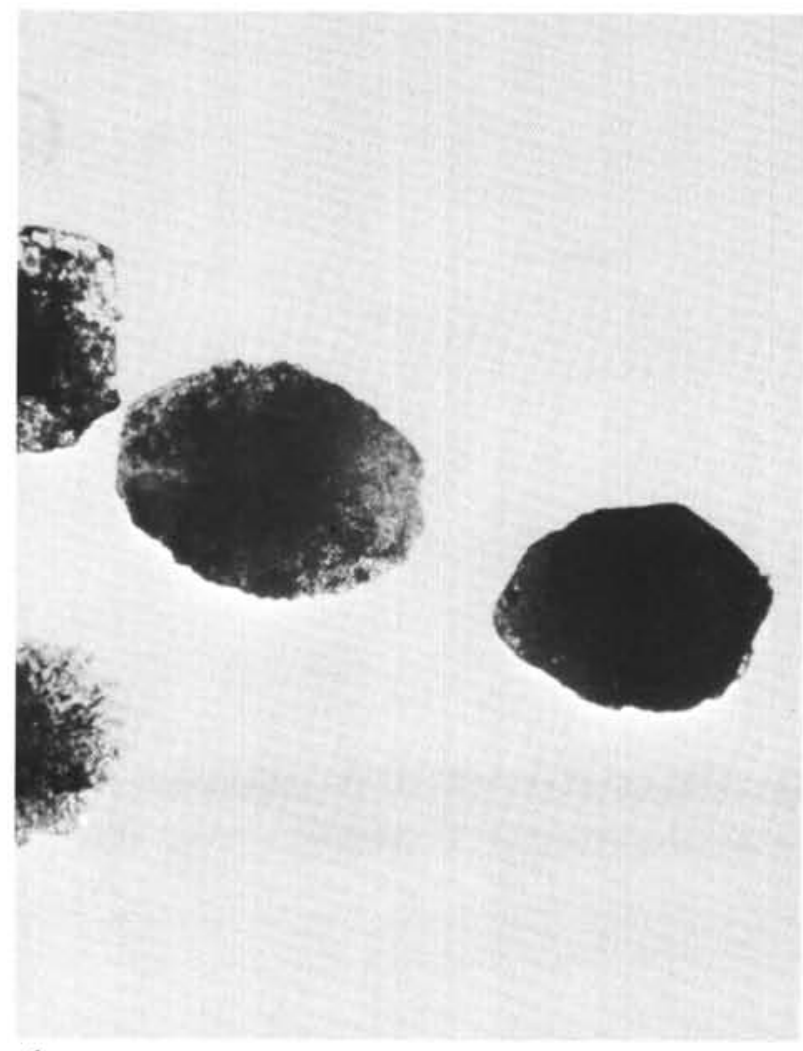

1
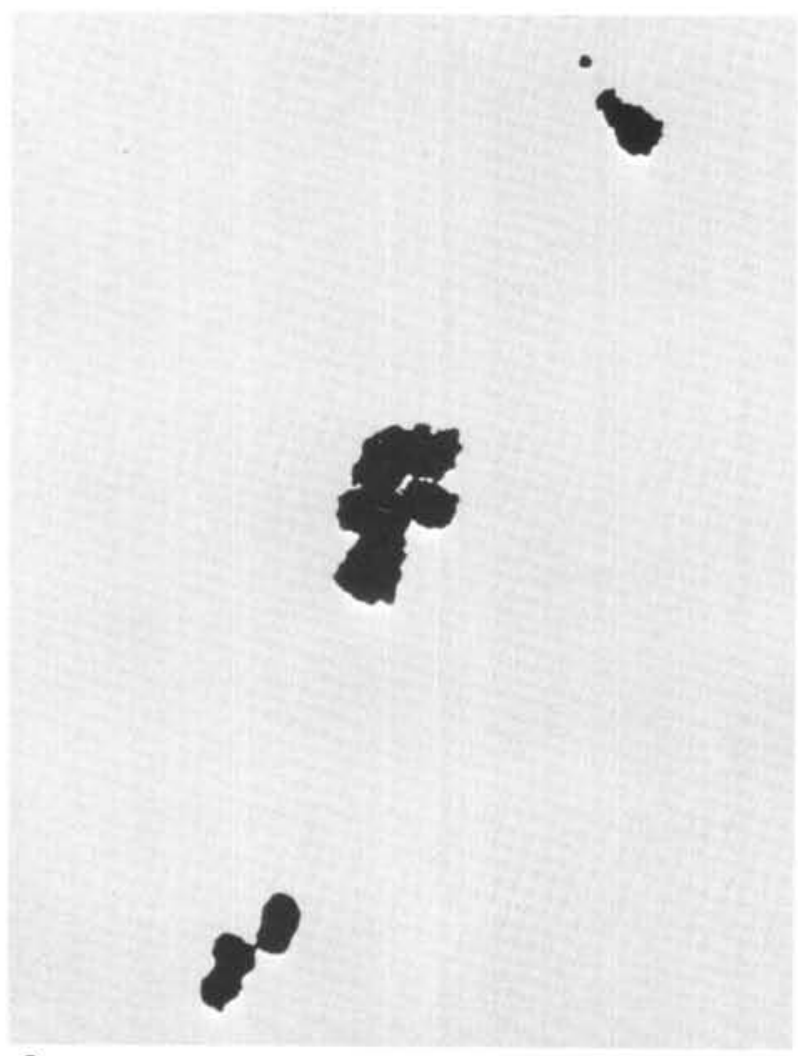
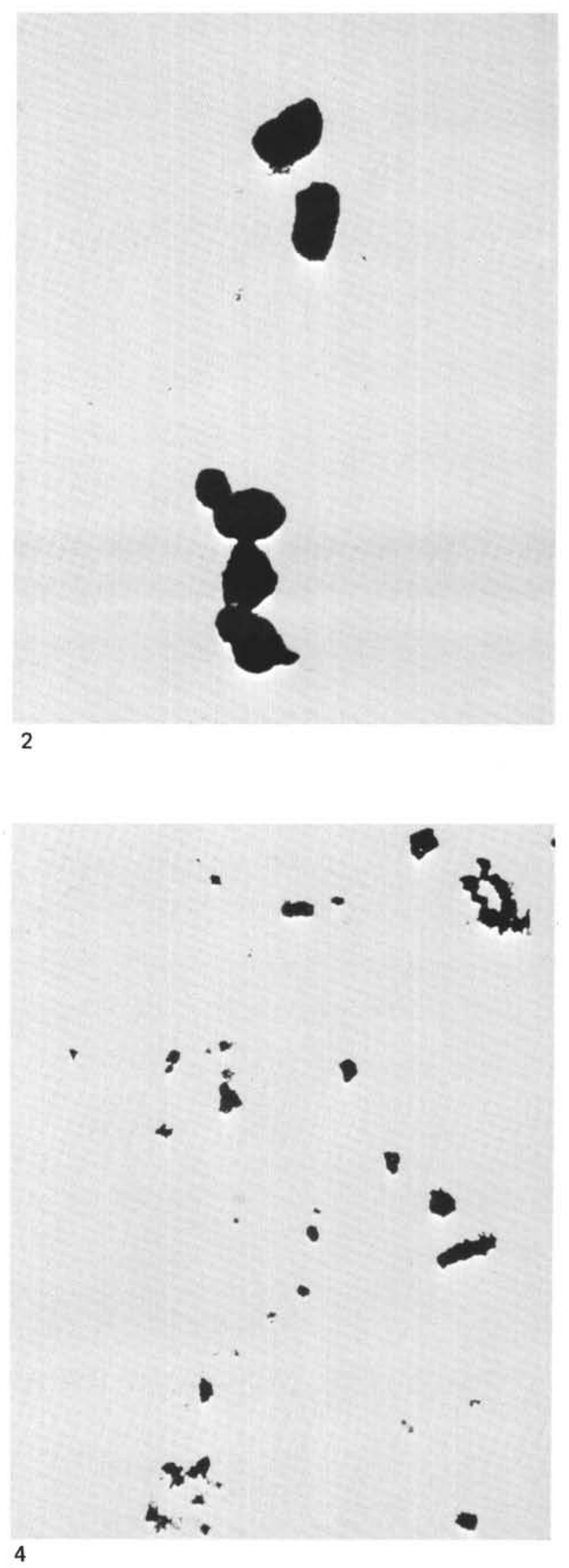


\section{PLATE 3}

Scanning electron microscope photographs and analysis of pure rhodochrosite.

Figure 1 Elongate hexagonal rhodochrosite, 200×, Sample 417A-10-3, $101-103 \mathrm{~cm}$.

Figure 2 Graph of the relative abundances (compared to manganese) of the elements analyzed with scanning electron microscope chemical analyses. (See also Table 1.) Note: $\mathrm{FC}=$ iron, cobalt.

Figure 3 Blocky (hexagonal) rhodochrosite. 175× Sample 417A-11-3, 54-56 cm.

Figure 4 Graph showing the relative abundance of the elements analyzed with the scanning electron microscope elemental analyzer. Note: FC $=$ iron, cobalt. 


\section{PLATE 3}

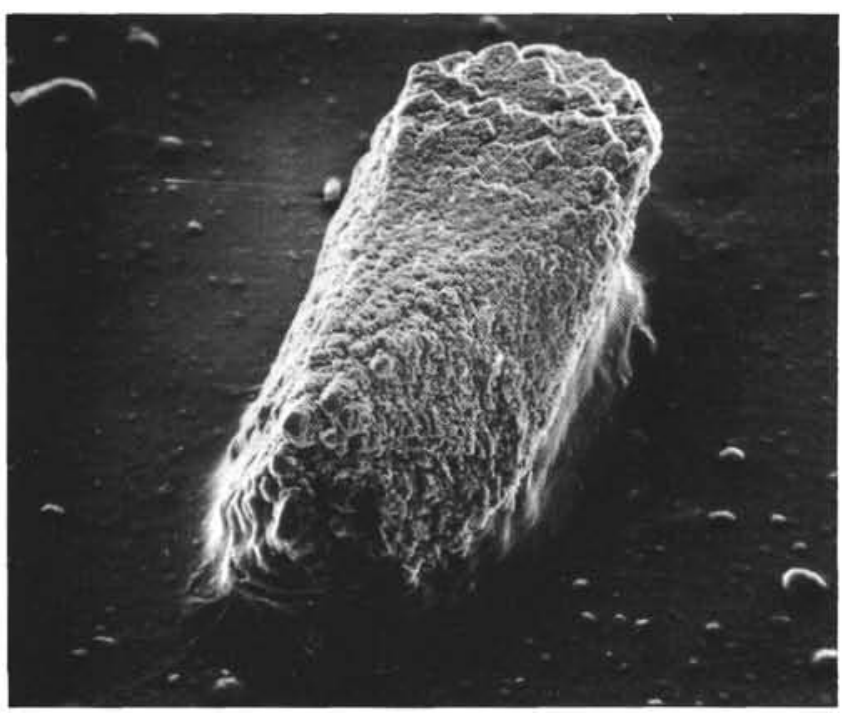

1

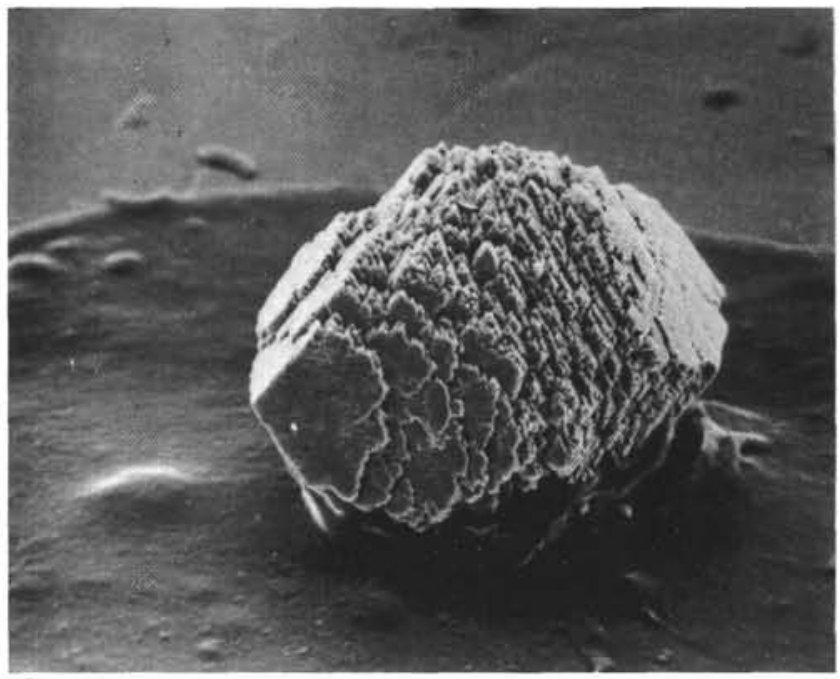

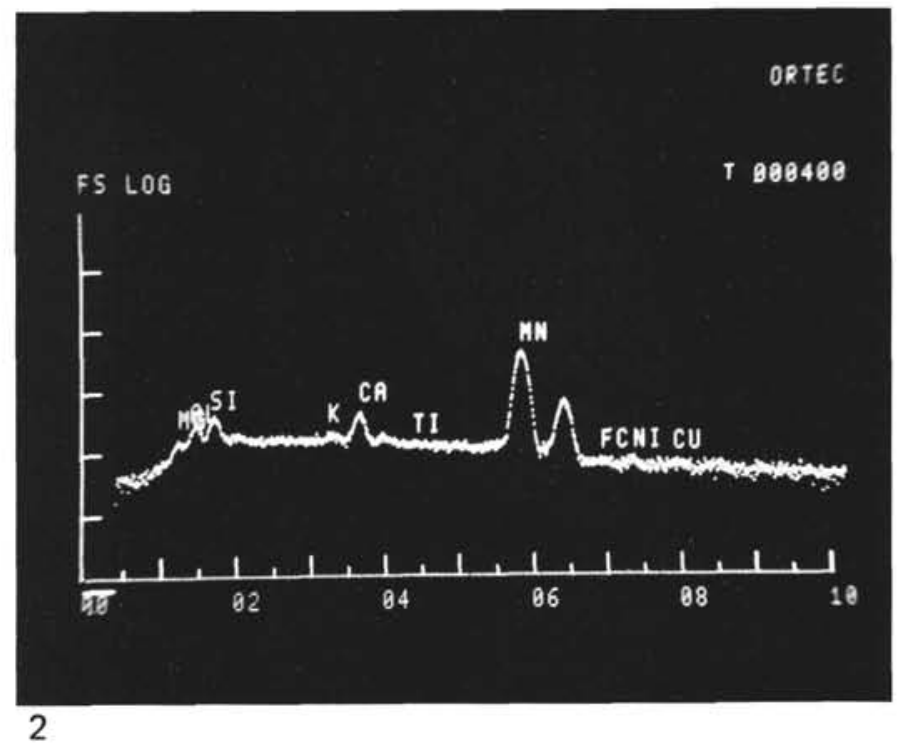

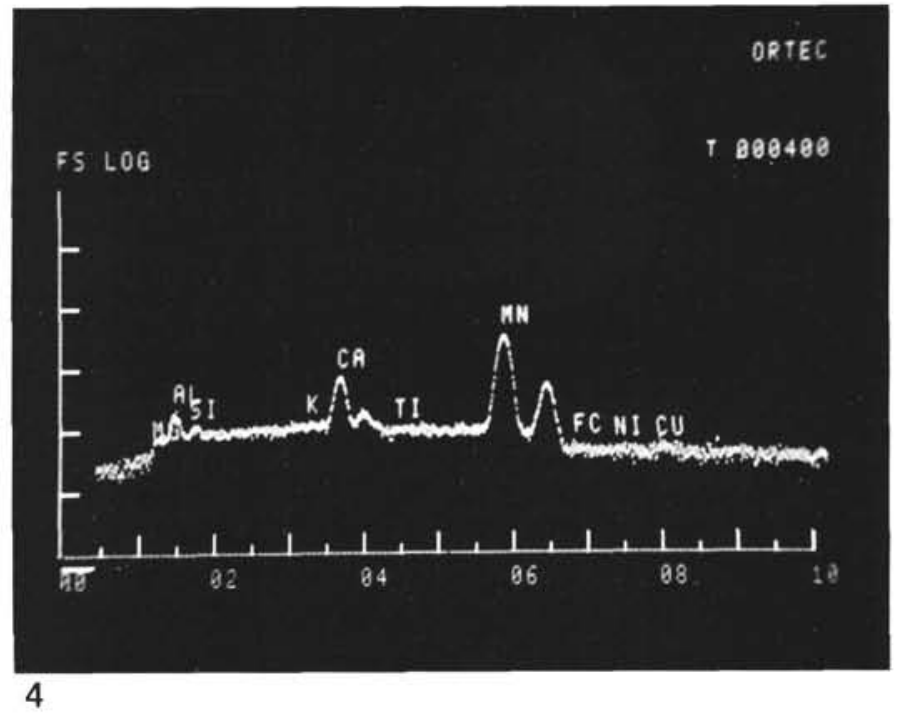




\section{PLATE 4}

Rhodochrosite crystals which have been completely transformed into manganese oxide.

Figure 1 Blocky rhodochrosite crystal completely transformed to manganese oxide, $417 \mathrm{~A}-9-3,130-132 \mathrm{~cm}, 175 \times$.

Figure 2 Graph of the relative abundance of elements analyzed with the Scanning Electron Microscope elemental analyzer. (See also Table 1.) Note: $\mathrm{FC}=$ iron, cobalt.

Figure 3 An elongate, twinned, rhodochrosite crystal completely transformed into manganese oxide. Sample 417A$10-3,101-103 \mathrm{~cm}, 200 \times$.

Figure 4 Graph showing the relative abundance of elements analyzed with the scanning electron microscope. 
PLATE 4

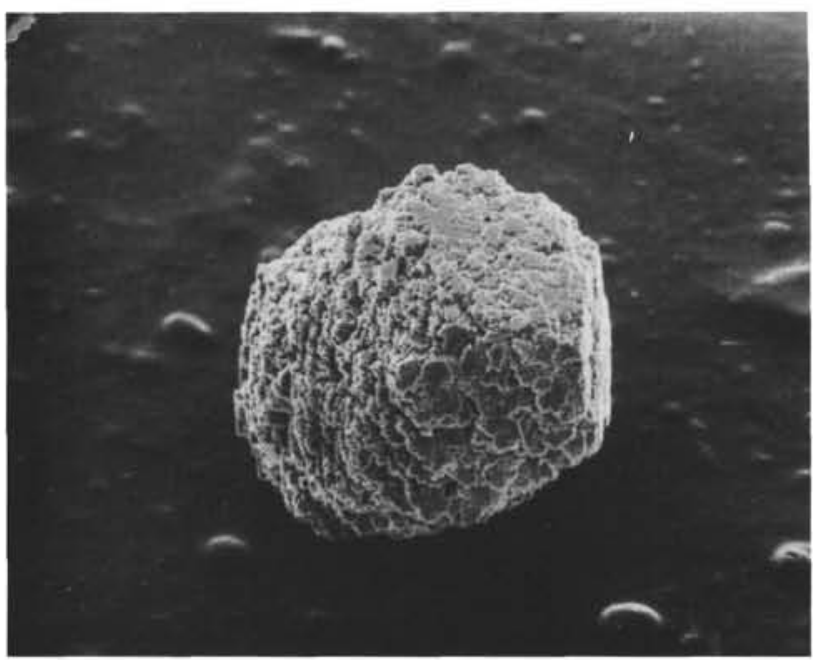

1

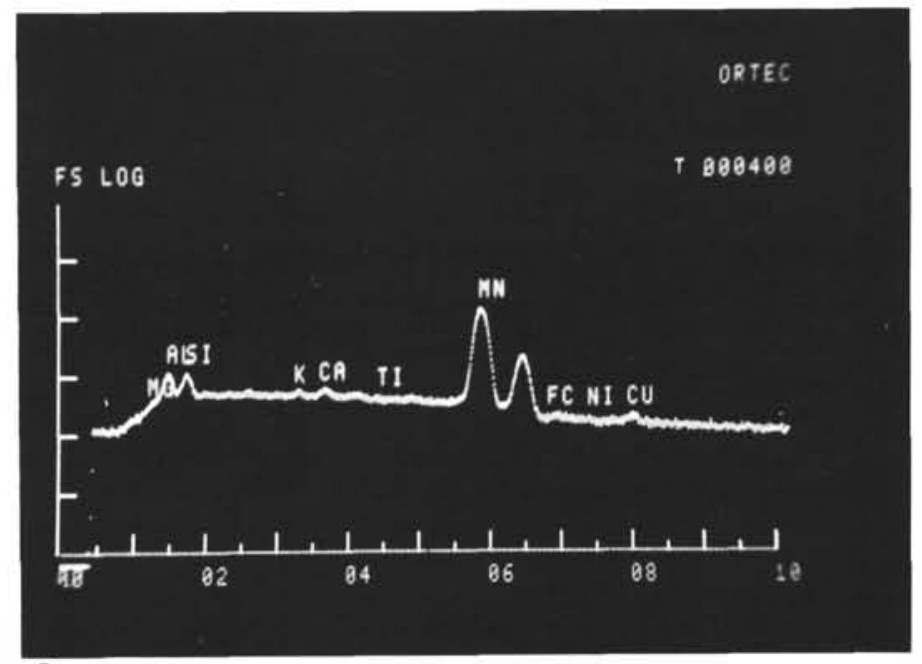

2
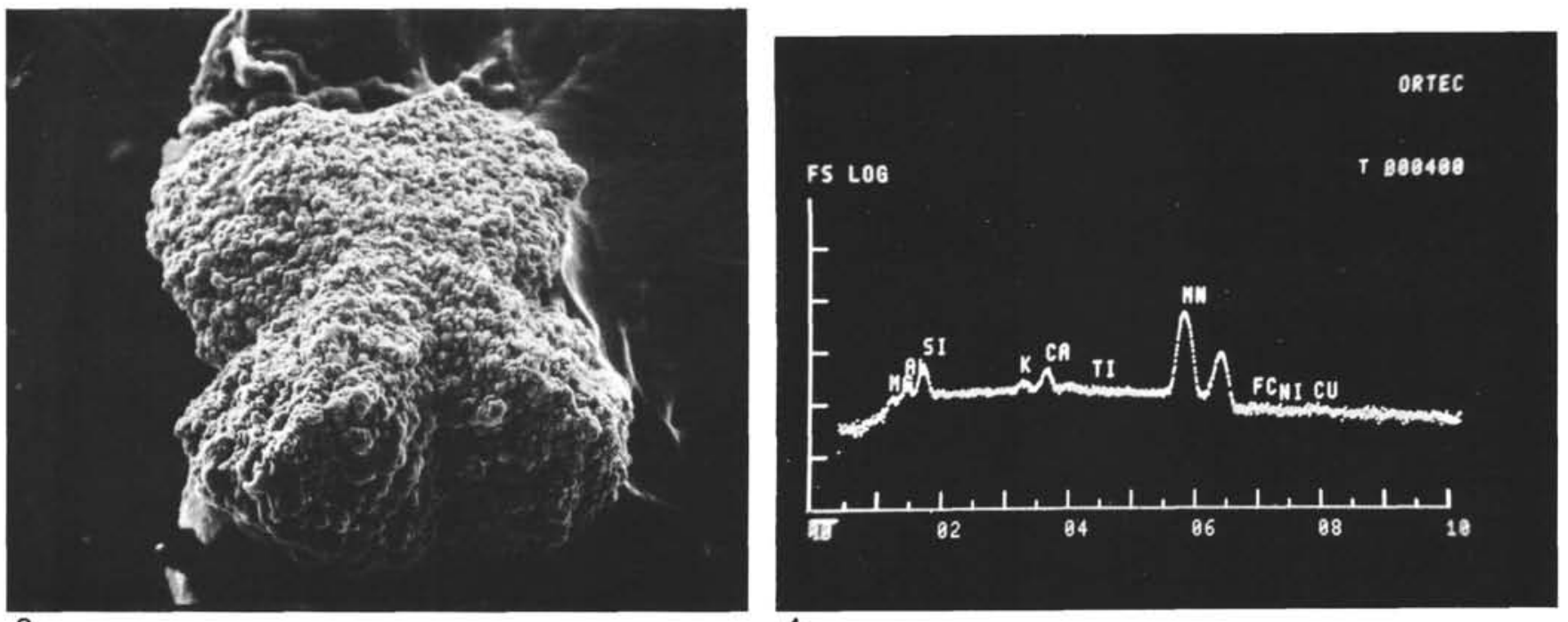


\section{PLATE 5}

Final stages in the transformation process.

Figure 1 Manganese oxide micronodule cluster found in Sample 417A-12-2, $43-45 \mathrm{~cm}, 165 \times$.

Figure 2 Graph showing the relative abundance of the elements analyzed with the scanning electron microscope. All measurements are based relative to manganese. A marked increase in many of the elements is observed as compared to the pure and transformed grains which retain the crystal form of the rhodochrosite. (See text for explanation.)

Figure 3 An unstructured growth on a blocky hexagonal rhodochrosite crystal. Sample 417A-9-3, 130-132 $\mathrm{cm}, 200 \times$.

Figure 4 Graph showing the relative abundance of the elements analyzed with the scanning electron microscope. The growth has increased amounts of $\mathrm{Mg}, \mathrm{Si}, \mathrm{K}, \mathrm{Ti}, \mathrm{Fe}$, and/or $\mathrm{Co}$ and $\mathrm{Ni}$ as compared to grain on which it is attached. See Table 1. 


\section{PLATE 5}
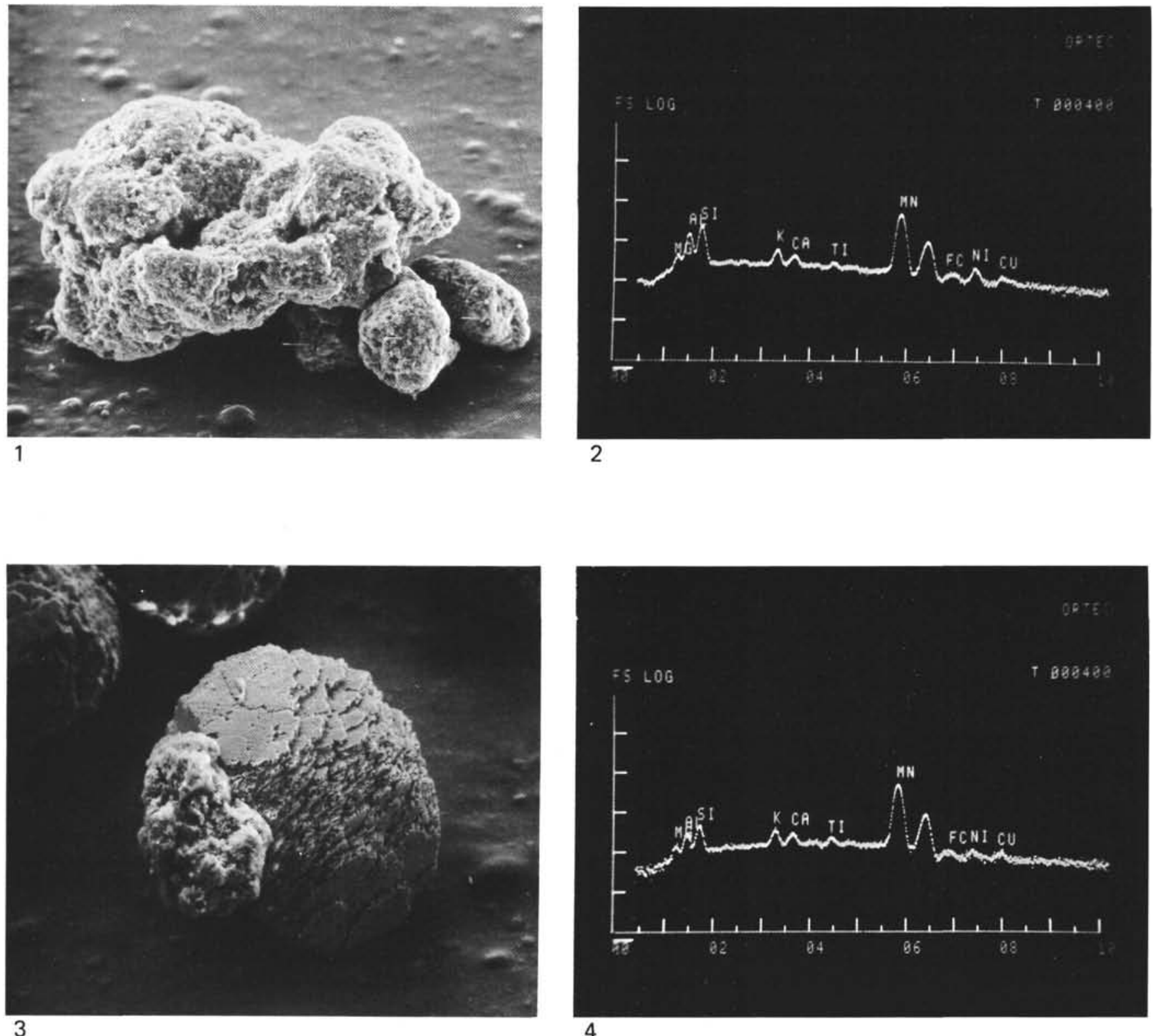